\title{
Editorial número especial
}

L a edición de la Revista Pensamiento Americano del área de Ciencias Sociales definida por la OCDE, presenta su edición especial que se refiere a los contextos sociales emergentes. Se compone de una sola sesión de artículos recibidos continuamente. Son artículos con temas variados, que, sin embargo, tienen proximidad y diálogo entre sí, a través de enfoques teóricos, ya sea por la temática tratada.

El primer artículo titulado Intervención en problemas familiares, Barrio La Divisa, Comuna 13 - Medellín es una encuesta a familias con problemas emocionales, socioculturales y cognitivos porque se insertan en un contexto no privilegiado, que afecta directamente la comunicación y la disciplina familiar a los niños. La investigación pasó por tres fases: diagnóstico, planificación, ejecución y evaluación que dieron como resultado el diagnóstico del cual surgieron siete microproyectos en la comunidad que van desde el abuso infantil hasta el plan de lectura. El trabajo fue escrito por Jeniffer Ximena Vega Fajardo y Sonia Lucía Vargas Amézquita

El artículo, La experiencia del Centro para los Derechos de las Personas con Discapacidad "y los Desafíos para la Efectividad de la Convención de las Naciones Unidas de 2007 aborda la experiencia de un proyecto de extensión destinado a identificar violaciones de derechos y prestación de asesoramiento jurídico gratuito para personas con discapacidad y de bajos ingresos. Con la Convención de las Naciones Unidas en 2007, las personas con discapacidad han ganado una mayor visibilidad, sin embargo, no vivimos en comunidades totalmente inclusivas y encontramos una verdadera falta de reconocimiento de la sociedad. Los autores Raquel Salle, Aline Passos y Nina Zaghetto señalan que con estas preocupaciones el proyecto desarrollado que resultó en la redacción del artículo, brindó una oportunidad académica para fortalecer una conciencia más sensible, atenta y proactiva en favor de las personas con discapacidad.

Pensar la sexualidad en la vejez fue el tema de la investigación realizada por Ramos Edgardo Callero, Ana del Carmen López y Estela Herrera, quien recibe el título "Propiedades psicométricas de las actitudes hacia la sexualidad en el cuestionario de la vejez (Casv-10). Medellín - Colombia ". El objetivo de este trabajo es evaluar las propiedades psicométricas del Cuestionario de Actitudes con respecto a la Sexualidad en la Vejez. Para la investigación, la muestra consistió en 300 personas, de 18 a 88 años de edad con un enfoque de muestra CAV-10. Los resultados son confiables y para una mejor comprensión es necesario leer el artículo con la interpretación de datos y tablas.

El cuarto artículo titulado "¿Son las teorías científicas estructuras, instrumentos o realidad?" trae un estudio de las teorías del realismo científico, con propuestas escépticas. El autor Andrés Álvarez-García argumenta que el realismo necesita establecer un conjunto de reglas para seleccionar entidades no observables, y que los modelos utilizados pueden describir una realidad dentro del marco de la ciencia madura. Las teorías científicas son reales cuando son producto de una ciencia madura.

"Las condiciones físicas y psicológicas de los cuidadores informales", trabajo escrito por Lina Maria Ortiz Vargas; Carolina Ramírezy Juan David Ortiz Polo, abordan un tema que surge del aumento de cuidadores sin una preparación adecuada para tal función que causa patologías (enfermedades) a estas personas. La metodología utilizada es una revisión de documentos que analizó 64 artículos y luego del análisis de criterios se seleccionaron 31 y 25 en español 6 en inglés. El resultado muestra que los cuidadores son parientes de primer grado, y los hombres tienen el índice más alto de agotamiento emocional cuando realizan esta actividad.

El artículo titulado "Psicología de la religión: reconocimiento teórico y descripción de la investigación" por los autores Mariluz Cano García y Helmer Quintero Núñez, expone revisiones históricas descriptivas de la psicología y la religión. Advierten sobre modificaciones conceptuales, diferentes enfoques y corrientes dentro de la subdisciplina que se afirma, como la naturaleza fenomenológica; y se revisan algunos estudios de investigación actuales por continentes. El modelo integral de la psicología de la religión se desarrolló a través de diferentes estudios con diferentes enfoques y paradigmas. El presente informe de investigaciones realizadas en diferentes regiones del mundo con prácticas cualitativas y cuantitativas y el esfuerzo por introducir corrientes alternativas, como la fenomenología. Los hechos 
religiosos son concebidos por nociones de psicología científica con evidencia empírica y evaluación integral.

El artículo escrito por Cristian Cardozo Mindiola, y se titula "Crítica retórica: teoría, aplicación y crítica". El trabajo aborda la crítica retórica, un enfoque hermenéutico que demuestra ser una herramienta útil para la hermenéutica literaria al colocar significados en los textos que crea la comunidad. Para resaltar este enfoque, el autor utiliza el análisis retórico para comprender el texto bíblico.

Para el profesor John José Libreros Díaz, el tema de los crímenes de Estado recibe especial atención, su trabajo titulado "Caracterización de los delitos estatales y el proceso de paz en Colombia". El tema central son los esfuerzos realizados en Colombia para lograr una paz estable y duradera. Al abordar el tema, el autor recorre campos delicados que involucran al estado y la guerrilla.

Pensar y creer en Dios es el tema de la obra Ciro Ernesto Redondo Mendonza y Luis Enrique Ribeiro Suárez, titulada "Confianza en el carácter y la salud mental de Dios". Los autores interpretan la relación existente en los niveles de salud mental a partir de las creencias sobre el carácter de Diosy su confianza en Dios, de las personas que pertenecen a comunidades cristianas. El estudio cuantitativo se realizó con 215 personas que asistieron a comunidades religiosas con base cristiana. Este análisis evidenció la alta presencia de salud mental y la confianza en Dios de estas personas, así como la confianza del carácter en Dios, independientemente de la edad o la asistencia a la iglesia. Para una mejor interpretación de los datos es necesario leer el artículo con el análisis de las tablas.

El artículo escrito por Mariby Boscan y Maryana Sandrea se titula "Desarrollo, negocios e innovación en el sector de fabricación de plástico de Zulian", y señala los cambios en el entorno y las transformaciones que las empresas están experimentando para adaptarse y desarrollarse en un sistema productivo que presenta cambios tecnológicos y necesidades para impulsar su negocio. El trabajo es un estudio descriptivo-documental y de campo, con un lanzamiento de transición no experimental. Claramente, es necesario estimular las innovaciones y motivar a todo el equipo para el desarrollo de la empresa.

El trabajo titulado "Fundamentos teóricos de la línea de investigación en educación religiosa", destaca que para la formación del ser humano la educación religiosa es un factor importante y está presente en toda la sociedad como un derecho mundial del ser humano. El desafío es la implementación de estrategias pedagógicas y curriculares en instituciones educativas en Colombia, especialmente en la escuela secundaria. El artículo pide que se respete este derecho en el sistema educativo. El trabajo fue escrito por Vanston irwin Archbold Hooker, Esteban Lozano Pulido, Hernán Berdejo González, Javier Molina Polo y Wilfredo Mora Julio de la Universidad Avendista.

El artículo escrito por Ruben Walter Huaranga Soto tiene como tema "Investigación científica o jurídica en las facultades de derecho de las universidades con licencia en Perú". El autor enfatiza la necesidad de otras metodologías para la investigación en el área del derecho, no solo utilizando la Metodología de la Práctica Jurídica sino también con bases filosóficas y sociológicas, proporcionando diferentes conocimientos.

Las limitaciones financieras y la escasez de recursos económicos disponibles para las universidades son barreras para que los jóvenes ingresen y completen la educación superior. Ante este problema, los autores Olandy naranjo Rivera, Gustavo Gregorutti, Carlos Willian Marín, Mario Enrique Vargar Sáenz, investigaron dos instituciones privadas (Colombia y Perú) de educación universitaria que implementaron mecanismos innovadores de financiamiento estudiantil. Los resultados indicaron que las IES desarrollan mecanismos de financiación basados en transacciones comerciales y no comerciales. El artículo se llama "Mecanismos de financiación que generan valor social y económico para la educación universitaria: un caso latinoamericano".

En relación con el artículo anterior, los autores Mallerlyn Rodríguez y Carlos Gallego presentan como tema de investigación la "Responsabilidad social de la universidad: perspectiva y contribuciones de una universidad confesional". Pensar en la responsabilidad social de las universidades implica dos aspectos, que responden a las demandas de su público y la importancia de actuar socialmente a través de la formación de individuos. El propósito de la investigación es describir la USR en la Adventist University Corporation, para mostrar la perspectiva y las contribuciones como una institución confesional hacia un modelo de gestión de Responsabilidad Social de la Universidad. 
Pensar en la producción científica de los profesores universitarios es un tema emocionante, ya que implica el período de dedicación, estímulo y desarrollo profesional de la misma. Los autores Carlos bastidas y Osbaldo Gebera, realizaron una investigación a través del análisis de artículos para presentar la situación de las instituciones de educación superior con respecto a la producción científica. La producción científica se considera un resultado primario del logro personal y profesional del autor de los profesores universitarios y, por lo tanto, contribuye a la mejora del rendimiento profesional. El trabajo final se llama "Factores que influyen en la producción científica de los profesores universitarios: una revisión sistemática".

El tema de la religiosidad se destaca en la edición de la revista American Thought, los autores Rachel Anaya, Helmer Quinteroy Willian Barrero, traen en el artículo un enfoque análogo al santuario del Éxodo, la experiencia historiográfica bíblica, donde presenta experiencias de salvación análoga. El artículo titulado Un enfoque multidimensional del Santuario del Éxodo como la Revelación de Dios utiliza un enfoque conceptual del santuario desde perspectivas antropológicas, arquitectónicas y pedagógicas para que el estudiante del siglo XXI pueda apropiarse de los conceptos críticos de esta verdad bíblica. El uso de la tecnología móvil fomenta el aprendizaje y motiva a los visitantes a explorar la profundidad semántica y trascendental detrás del santuario del éxodo.

El último artículo que se presentará "Bioeconomía en el mundo moderno: una revisión de la literatura de los 5 continentes", recorre los países del mundo que han documentado y difundido información sobre la bioeconomía y han presentado definiciones o estrategias políticas, así como pautas para su desarrollo. Para buscar datos, se realizó una revisión de la literatura que presenta una visión general de cómo está ocurriendo la bioeconomía en diferentes países del mundo. 


\section{Editorial special issue}

The Social Sciences edition of the American Thought Journal defined by the OECD presents its special edition that refers to emerging social contexts. It consists of a single session of articles received continuously. They are articles with varied themes, which, notwithstanding, have proximity and dialogue with each other, either through theoretical approaches or by the subject matter covered.

The first article entitled intervention in family problems, Barrio La Divisa, Comuna 13 - Medellín is a survey of families with emotional, sociocultural and cognitive problems because they live in an unprivileged social context, which directly affects communication and family discipline in children. The research went through three phases: diagnosis, planning, execution and evaluation that resulted in the diagnosis from which seven microprojects emerged in the community, ranging from child abuse to the reading plan. The work was written by Jeniffer Ximena Vega Fajardo and Sonia Lucía Vargas Amézquita

The article, "The Experience of the Center for the Rights of Persons with Disabilities" and the Challenges to the Effectiveness of the 2007 United Nations Convention, addresses the experience of an extension project aimed at identifying rights violations and providing free legal advice for people with disabilities and low-income people. With the United Nations Convention in 2007, people with disabilities have gained greater visibility, however, we do not live in fully inclusive communities and find a real lack of recognition of society. The authors Raquel Salle, Aline Passos and Nina Zaghetto point out that with these concerns, the developed project that resulted in the writing of the article provided an academic opportunity to strengthen a more sensitive, attentive and proactive conscience in favour of people with disabilities.

Thinking about sexuality in old age was the subject of research carried out by Ramos Edgardo Callero, Ana del Carmen López and Estela Herrera, which is entitled "Psychometric properties of attitudes towards sexuality in the old age questionnaire (Casv-10). Medellín - Colombia". This work aims to evaluate the psychometric properties of the Attitudes Questionnaire regarding Sexuality in Old Age. For the research, the sample consisted of 300 people, from 18 to 88 years old with a focus of sample CAV-10. The results are reliable and for a better understanding, it is necessary to read the article with the interpretation of data and tables.

The fourth article entitled "Are Scientific Theories Structures, Instruments, or Reality?" brings a study of the theories of scientific realism, with skeptical proposals. The author Andrés Álvarez-García argues that realism needs to establish a set of rules to select unobservable entities, and that the models used can describe a reality within the framework of mature science. Scientific theories are real when they are the product of mature science.

"The physical and psychological conditions of informal caregivers", paper written by Lina Maria Ortiz Vargas; Carolina Ramírez and Juan David Ortiz Polo, address a topic that arises from the increase in caregivers without adequate preparation for such a function that causes pathologies (diseases) to these people. The methodology used is a review of documents that analyzed 64 articles and after the analysis of criteria, 31 and 25 were selected in Spanish and 6 in English. The result shows that caregivers are first degree relatives, and men have the highest rate of emotional exhaustion when doing this activity.

The article entitled "Psychology of religion: theoretical recognition and description of research" by the authors Mariluz Cano García and Helmer Quintero Núñez, presents descriptive historical reviews of psychology and religion. They warn about conceptual modifications, different approaches and currents within the affirmed subdiscipline, such as the phenomenological nature; and some current research studies by continents are reviewed. The comprehensive model of the psychology of religion was developed through different studies with different approaches and paradigms. The present report of investigations carried out in different regions of the world with qualitative and quantitative practices and the effort to introduce alternative currents, such as phenomenology. Religious events are conceived by notions of scientific psychology with empirical evidence and comprehensive evaluation.

The article titled "Rhetorical criticism: theory, application and criticism" written by Cristian Cardozo Mindiola,

Pensamiento Americano Vol. 11 (22) · 2018 • Julio-Diciembre · Corporación Universitaria Americana • Barranquilla, Colombia • ISSN: $2027-2448$. http://publicaciones.americana.edu.co/index.php/pensamientoamericano/index 
addresses rhetorical criticism, a hermeneutical approach that proves to be a useful tool for literary hermeneutics by placing meanings in the texts that the community creates. To highlight this approach, the author uses rhetorical analysis to understand the biblical text.

For professor John José Libreros Díaz, the topic of state crimes receives special attention, his work entitled "Characterization of state crimes and the peace process in Colombia". The central issue is the efforts made in Colombia to achieve a stable and lasting peace. Addressing the topic, the author traverses delicate fields that involve the state and the guerrillas.

Thinking and believing in God is the theme of paper of Ciro Ernesto Redondo Mendonza and Luis Enrique Ribeiro Suárez, entitled "Trust in the character and mental health of God". The authors interpret the existing relationship in the levels of mental health from the beliefs about the character of God and their trust in God, of the people who belong to Christian communities. The quantitative study was conducted with 215 people who attended Christianbased religious communities. This analysis evidenced the high presence of mental health and trust in God of these people, as well as the trust of character in God, regardless of age or church attendance. For a better interpretation of the data, it is necessary to read the article with the analysis of the tables.

The article written by Mariby Boscan and Maryana Sandrea is titled "Development, business and innovation in the Zulian plastic manufacturing sector", and point out the changes in the environment and the transformations that companies are experiencing to adapt and develop in a system productive that presents technological changes and needs to boost its business. The work is a descriptive-documentary and field study, with a non-experimental transitional launch. Clearly, it is necessary to stimulate innovations and motivate the entire team for the development of the company.

The paper entitled "Theoretical foundations of the line of research in religious education", highlights that for the formation of the human being, religious education is an important factor and is present throughout society as a world human right. The defiance is the implementation of pedagogical and curricular strategies in educational institutions in Colombia, especially in secondary school. The article asks that this right be respected in the educational system. The work was written by Vanston Irwin Archbold Hooker, Esteban Lozano Pulido, Hernán Berdejo González, Javier Molina Polo and Wilfredo Mora Julio from Avendista University.

The article written by Ruben Walter Huaranga Soto has as its subject "Scientific or legal research in the law schools of the universities licensed in Peru". The author emphasizes the need for other methodologies for research in the area of law, not only using the Methodology of Legal Practice but also with philosophical and sociological bases, providing different knowledge.

Financial constraints and the scarcity of financial resources available to universities are barriers for young people to enter and complete tertiary education. Faced with this problem, the authors Olandy Naranjo Rivera, Gustavo Gregorutti, Carlos Willian Marín, Mario Enrique Vargar Sáenz, investigated two private institutions (Colombia and Peru) of university education that implemented innovative student financing mechanisms. The results indicated that HEls develop financing mechanisms based on commercial and non-commercial transactions. The article is called "Financing mechanisms that generate social and economic value for university education: a Latin American case".

Regarding the former article, the authors Mallerlyn Rodríguez and Carlos Gallego present the "Social responsibility of the university: perspective and contributions of a confessional university" as a research topic. Thinking about the social responsibility of universities involves two aspects, which respond to the demands of their public and the importance of acting socially through the training of individuals. The purpose of the research is to describe USR at the Adventist University Corporation, to show the perspective and contributions as a denominational institution towards a University Social Responsibility management model.

Thinking about the scientific production of university professors is an exciting topic since it involves the period of dedication, encouragement and professional development of the same. The authors Carlos Bastidas and Osbaldo 
Gebera, researched through the analysis of articles to present the situation of higher education institutions concerning scientific production. Scientific production is considered a primary result of the personal and professional achievement of the author of university professors and, therefore, contributes to the improvement of professional performance. The final work is called "Factors that Influence the Scientific Production of University Professors: A Systematic Review".

The topic of religiosity is highlighted in the issue of the American Thought magazine, the authors Rachel Anaya, Helmer Quintero and Willian Barrero, bring in the article an analogous approach to the sanctuary of Exodus, the biblical historiographical experience, where it presents experiences of analogous salvation. The article entitled A Multidimensional Approach to the Shrine of Exodus as the Revelation of God uses a conceptual approach to the shrine from anthropological, architectural and pedagogical perspectives so that the 21st-century student can appropriate the critical concepts of this Biblical truth. The use of mobile technology encourages learning and motivates visitors to explore the semantic and transcendental depth behind the sanctuary of the Exodus.

The last article to be presented "Bioeconomy in the Modern World: A Review of the Literature of the 5 Continents", covers the countries of the world that have documented and disseminated information on the bioeconomy and have presented definitions or political strategies, as well as guidelines for its development. To search for data, a literature review was performed that presents an overview of how the bioeconomy is occurring in different countries of the world. 
A edição da Revista Pensamento Americano da área de Ciências Sociais definida pela OCDE, apresenta sua edição especial que refere-se a Contextos Sociais Emergentes. A mesma está composta por uma sessão única de artigos recebidos de forma contínua. São artigos com temas variados, que, no entanto, possuem proximidades e dialogam entre si, por meio de abordagens teóricas, seja pelas temáticas tratadas.

O primeiro artigo intitulado Intervenção em problemas familiares, bairro la divisa, comuna 13 - Medellíné uma pesquisa realizada com famílias que apresentam problemas emocionais, socioculturais e cognitivos por estarem inseridas em um contexto não privilegiado o que afeta diretamente a comunicação em família e a disciplina com as crianças. A pesquisa passou por três fases: diagnóstico, planejamento, execução e avaliação que resultou em diagnóstico da qual surgiram sete microprojetos para serem realizados na comunidade que envolvem desde abuso infantil á plano de leitura. O trabalho foi escrito por Jeniffer Ximena Vega Fajardo e Sonia Lucía Vargas Amézquita

O artigo, "A experiência do "Núcleo de Direitos das Pessoas com Deficiência" e os desafios para a efetividade da Convenção das Nações Unidas de 2007 contempla a experiência realizada em um projeto de extensão que teve por objetivo a identificação de violações de direitos e a prestação de assessoria jurídica gratuita para pessoas com deficiência e baixa renda. Com a convenção das nações Unidas em 2007, as pessoas com deficiência ganharam uma maior visibilidade, apesar disso não vivemos em comunidades totalmente inclusiva e encontramos uma ausência real de reconhecimento da sociedade. As autoras Raquel Salle, Aline Passos e Nina Zaghetto destacam que com estes inquietamentos o projeto desenvolvido que resultou na escrita do artigo, oportunizou em âmbito acadêmico o fortalecimento de consciência mais sensível, atenta e pro ativa á favor das pessoas com deficiências.

Pensar a sexualidade na terceira idade, foi tema do trabalho dos pesquisadores Ramos Edgardo Callero, Ana del Carmen López e Estela Herrera, que recebe o título "Propriedades psicométricas das atitudes em relação à sexualidade no questionário para velhice (Casv-10). Medellín - Colômbia". O trabalho traz por objetivo avaliar as propriedades psicométricas do Questionário de Atitudes em relação à Sexualidade na Velhice. Para a realização da pesquisa a amostra foi de 300 pessoas, entre idade de 18 á 88 anos de idade com abordagem em amostra CAV-10. Os resultados são confiáveis e para melhor entendido se faz necessário a leitura do artigo com a intepretação dos dados e tabelas.

O quarto artigo que tem por titulo "As teorias científicas são estruturas, instrumentos ou realidade? " traz um estudo sobre as teorias do realismo científico, com criticidade as propostas céticas. O autor Andrés Álvarez-Garcia, argumenta que o realismo precisa estabelecer um conjunto de regras para que possa selecionar entidades não observáveis, e que os modelos utilizados podem vir a descrever uma realidade dentro da estrutura da ciência madura. As teorias científicas são reais quando são produto de uma ciência madura.

"As condições físicas e psicológicas de cuidadores informais", trabalho escrito por Lina Maria Ortiz Vargas; Carolina Ramírez e Juan David Ortiz Polo, aborda um tema decorrente do aumento de cuidadores sem preparo adequado para tal função o que ocasiona patologias (doenças) á estas pessoas. A metodologia utilizada é de revisão documental que analisou 64 artigos e após análise de critérios 31 foram selecionados sendo 25 em espanhol 6 em inglês. O resultado aponta que os cuidadores são parentes de primeiro grau, e os homens apresentam o maior indicie de esgotamento emocional ao exercer esta atividade.

O artigo intitulado "Psicologia da religião: reconhecimento teórico e panorama de pesquisa" dos autores Mariluz Cano García e Helmer Quintero Núñez, expõem revisões históricas descritivas da psicologia e da religião. Eles alertam sobre as modificações conceituais, diferentes abordagens e correntes dentro da subdisciplina que estão sendo afirmadas, como a natureza fenomenológica; e alguns estudos de pesquisa atuais por continentes são revisados. O modelo abrangente da psicologia da religião foi desenvolvido através de diferentes estudos com diferentes abordagens e paradigmas. O presente relato de pesquisas realizadas em diferentes regiões do mundo com práticas qualitativas e quantitativas e o esforço para introduzir correntes alternativas, como a fenomenologia. Os fatos religiosos são pretendidos por noções de psicologia científica com evidências empíricas e com avaliação abrangente.

O artigo escrito por Cristian Cardozo Mindiola, e traz por título "Crítica retórica: teoria, aplicação e crítica", versa sobre a crítica retórica, uma abordagem hermenêutica que mostra ser uma ferramenta útil para a hermenêutica literária colocando significados nos textos que a comunidade o cria. Para evidenciar esta abordagem o autor utiliza na análise retórica para a compreensão do texto bíblico.

Para o professor John José Libreros Díaz o tema de crimes do estado recebe uma atenção especial, seu trabalho traz como título "Caracterização dos crimes de Estado e o processo de paz na Colômbia". O tema central são os esforços realizados na Colômbia para alcançar a paz estável e duradoura. Ao abordar o tema o autor perpassa campos delicados que envolvem Estado e guerrilheiros.

Pensar e crer em Deus é tema do trabalho de Ciro Ernesto Redondo Mendonza e Luis Enrique Ribeiro Suarez que recebe como título "Confiança no caráter de Deus e na saúde mental". Os autores interpretam a relação existente nos níveis de saúde mental a partir das crenças sobre o caráter de Deus e sua confiança nele, de pessoas que pertencem as comunidades de fundamento cristão. $O$ estudo 
de cunho quantitativo foi realizado com 215 pessoas que frequentam comunidades religiosas de fundamento cristão. Esta análise evidenciou a alta presença de saúde mental e confiança em Deus destas pessoas, além de confiança de caráter no Deus independe de idades ou dos anos que frequentam a igreja. Para melhor intepretação dos dados se faz necessária a leitura do artigo com análise das tabelas.

O artigo escrito por Mariby Boscan e Maryana Sandrea se intitula "Desenvolvimento e negócios e inovação no setor de fabricação de plástico Zulian", aponte as mudanças do meio ambiente e as transformações que as empresas experimentam para se adequar e se desenvolver em um sistema produtivo que apresenta mudanças tecnológicas e precisa impulsionar seus negócios. O trabalho é um estudo de tipo descritivo-documental e de campo, com um release transitório não experimental. É evidente que se faz necessário o estimulo das inovações e a motivação toda a equipe para o desenvolvimento da empresa.

O trabalho intitulado "Fundamentos Teóricos da linha de pesquisa em educação religiosa", destaca que para a formação do ser humano a educação religiosa é um fator importante e se faz presente em toda a sociedade sendo um direito mundial ao ser humano. O desafio encontrado está na implementação das estratégias pedagógicas e curriculares nas instituições educativas na Colômbia em especial no ensino médio. O artigo faz um convite para que este direito seja respeitado no sistema educativo. $O$ trabalho foi escrito por Vanston irwin Archbold hooker, Esteban Lozano Pulido, Hernán Berdejo González, Javier Molina Polo e Wilfredo Mora Julio da Universidade Avendista.

O artigo escrito por Ruben Walter Huaranga Soto, traz como temática a "Pesquisa científica ou jurídica nas faculdades de direito de universidades licenciadas do Peru". O autor evidencia a necessidade de outras metodologias para pesquisa na área do direito, não apenas utilizando a Metodologia de Prática Jurídica, mas ás com base filosóficas e sociológicas oportunizando saberes diferentes.

As restrições financeiras e a escassez de recursos econômicos disponíveis nas universidades são barreiras para que jovens possam ingressar e concluir o ensino superior. Diante desse problema os autores Olandy naranjo Rivera, Gustavo Gregorutti, Carlos Willian Marin, Mario Enrique Vargar Saenz, pesquisaram duas instituições privadas (Colômbia e Peru) de ensino universitário que implementaram mecanismos inovadores de financiamento aos estudantes. Os resultados indicaram que as IES desenvolvem mecanismos de financiamentos baseados em transações comerciais e não comerciais. O artigo recebe o nome "Mecanismos de financiamento que geram valor social e econômico para o ensino universitário: um caso latino-americano".

Estabelecendo um link com o artigo anterior os autores Mallerlyn Rodriguez e Carlos Gallego apresentam como temática de pesquisa a "Responsabilidade Social da Universidade: Perspectiva e contribuições de uma universidade confessional". Pensar em responsabilidade social de universidades envolve dois aspectos, responder às demandas de seu público e a importância de agir socialmente por meio da formação dos indivíduos. O objetivo da pesquisa é descrever a USR na Adventist University Corporation, para mostrar a perspectiva e as contribuições como instituição confessional em direção a um modelo de gestão de Responsabilidade Social da Universidade.

Pensar a produção científica de professores universitários é um tema que instiga, visto que envolve o período de dedicação, o incentivo e o desenvolvimento profissional do mesmo. Os autores Carlos bastidas e Osbaldo Gebera, realizaram uma pesquisa através de análise de artigos para apresentar a situação das instituições de educação superior no que se refere a produção científica. A produção científica é considerada um resultado primário da autor realização pessoal e profissional dos professores universitários e, portanto, contribui para a melhoria do desempenho profissional. O trabalho final recebe o nome "Fatores que influenciam a produção científica de professores universitários: uma revisão sistemática".

A temática da religiosidade recebe destaque na edição da Revista Pensamento Americano, os autores Rachel Anaya, Helmer Quintero e Willian Barrero, trazem no artigo uma abordagem análoga em relação ao santuário do Êxodo, experiência historiográfica bíblica, onde apresenta experiências da salvação análoga. O artigo intitulado Uma abordagem multidimensional do santuário do Êxodo como revelação de Deus utiliza uma abordagem conceitual do santuário a partir das perspectivas antropológicas, arquitetônicas e pedagógicas, para que o estudante do século XXI possa se apropriar dos conceitos críticos dessa verdade bíblica. O uso da tecnologia móvel incentiva o aprendizado e motiva os visitantes a explorar a profundidade semântica e transcendental por trás do santuário do Êxodo.

O último artigo a ser apresentado "A bioeconomia no mundo moderno: uma revisão da literatura dos 5 continentes", faz um tour pelo países do mundo que documentaram e divulgaram informações sobre a bioeconomia e apresentaram definições políticas ou estratégias, além de terem diretrizes para seu desenvolvimento. Para a busca de dados foi realizada um revisão da literatura apresentando uma visão geral de como está acontecendo a bioeconomia nos diferentes países do mundo. 